\title{
U.S. Foreign Policy on the Verge of a New Path
}

\author{
O. V. Prikhodko\# \\ Institute for the U.S. and Canadian Studies, \\ Russian Academy of Sciences (ISKRAN), Russia, Moscow \\ e-mail: olegvladim@yandex.ru \\ Received on November 26, 2020
}

\begin{abstract}
In the course of the election campaign, a heated contest between President Donald Trump and Joe Biden revolved around the most acute problems of the United States. However, some foreign policy issues, primarily linked with Russia and China, occasionally emerged in their debates. The outcome of the presidential election of 2020 marked a watershed in the political fight for the White House between Republicans and Democrats, and it will have a tremendous impact on international affairs. The election campaign was unfolding amid the COVID-19 pandemic. Responding to the challenge has revealed a discord between the United States and the European Union on how to tackle the crisis and their opposite perceptions of the WHO's role. President-elect J. Biden is about to cancel D. Trump's dubious decisions on U.S. withdrawal from the Iranian nuclear deal, the Paris accord on climate, the World Health Organization. This reversal may lead to a more alignment between the United States and the European Union, but it can't prevent ongoing erosion of the U.S.A global hegemony. Biden's election is in no way a guarantor for overcoming of transatlantic disagreements. American presidents come and go but diverging and conflicting interests of the United States and the EU remain.
\end{abstract}

Keywords: D. Trump, J. Biden, U.S. presidential election, U.S. foreign policy, the European Union, transatlantic relationship, pandemic COVID-19.

DOI: $10.18254 / \mathrm{S} 207987840015223-4$

This article is a translation of: Приходько O.B. Внешняя политика США на пороге нового этапа // США \& Канада: экономика, политика, культура. 2021. № 2. С. 18-37. DOI: 10.31857/S268667300013565-1

\section{INTRODUCTION}

Presidential elections in the United States have almost always had a significant influence on the American foreign policy. But it is hard to remember any time in the recent decades when they would attract such close attention of the world community as in 2020.The outcome of the vote which took place amid a political crisis and the rampant COVID-19 pandemic, in many ways determines the prospect of international relations for the foreseeable future since D. Trump and J. Biden personify fundamentally different approaches to the positioning of the United States in the world. The elections were followed with particular concern in Europe, where opinions were expressed that that the re-election of the 45th President of the United States would prove fatal for NATO, aggravating internal disagreements that could lead to its

\# Cand. Sci. (History), leading researcher, Institute for the U.S. and Canadian Studies, Russian Academy of Sciences (ISKRAN), 2/3 Khelbny per., Moscow 121069, Russian Federation. split, while the success of the Democratic candidate, on the contrary, would breathe new life into the Alliance. Many Western political scientists, champions of the ideas of neoliberalism, saw in Trump the gravedigger of the liberal international order. Critics of Trump saw great risks for the future of transatlantic relations in the potentially unfavorable outcome of the vote, worrying that, if re-elected, he might try to fulfill his intention to withdraw the United States from NATO [1]. However, most American pundits still believed that «the entrenched foreign policy consensus on U.S. policy toward NATO is likely to survive Trump». [Sperling J., 2019: 421].

Admitting the possibility of D. Trump's win in the elections, the French political scientist F. Heisbourg stated several months before the vote: «There is currently no unity of vision between the US and its European partners: Trump has been consistent in his transactional and (wherever possible) unilateral approach. He is unlikely to change, and whether he will 
be defeated in the November 2020 presidential election remains highly uncertain» [Heisbourg F., 2020: 15]. According to F. Heisbourg, if the trends of recent years continue, «Trump's 'America First' policy would morph into more broadly based isolationism». F. Heisbourg assumed that if J. Biden wins, he will be preoccupied with the country's pressing problems: «Even if Trump's successor were the functional equivalent of Roosevelt, it is wise to remember that the New Deal president's first two terms were hardly internationalist» [Heisbourg F., 2020: 17].

U.S. administrations replace each other as the result of elections but national interests remain. The defeat of Trump, who in the liberal Europe was associated with the threat of a split in the Atlantic community, does not automatically mean an accommodation of the conflicting interests of the United States and the EU. However, it was J. Biden's victory that the leaders of the major European powers as well as the leaders of the EU and NATO hoped for, who rushed to send him congratulations a few days after the elections, without waiting for the official elections results. Many countries of Eastern Europe, especially Poland and Hungary, used to seeing Trump as their ally in the disputes with Brussels, were in favor of his re-election.

Due to the extremely tense atmosphere of the election campaign, the situation around the coronavirus pandemic in the United States acquired a highly politicized character, which was also reflected in D. Trump's response to the crisis, including its international aspects - from the closure of the borders and accusations against China to the severing of relations with WHO. Judging by J. Biden's statements, the U.S. approach to this issue will change, and his predecessor's most controversial decisions will be revised. At the same time, the new administration cannot ignore the fact that the race for leadership in the production of vaccines and drugs for COVID-19 between the U.S., EU, China and Russia is gaining momentum, since international prestige and immense income from the sales of coronavirus drugs in the global market is at stake.

\section{INTERNATIONAL ISSUES IN THE ELECTION STRUGGLE BETWEEND. TRUMP AND J. BIDEN}

The most acute internal problems of the United States were at the forefront in the election campaigns of the two leading contenders for the presidency - the fight against the coronavirus pandemic and the overcoming of its consequences, eradicating of racism, competing proposals by Republicans and Democrats for the change of the tax system and the national energy strategy. Foreign policy issues were also present in the contest between D. Trump and J. Biden, though the verbal duel between them often slid into mutual accusations of indulgence towards the enemies of the United States instead of a meaningful discussion of the issues. The campaign headquarters of the Democratic candidate reminded voters that J. Biden had a long track record of participation in foreign affairs, first as a Senator and then as Vice President. However, this experience, according to the former Defense Secretary R. Gates, did not help J. Biden to correctly perceive the international problems that the Obama administration faced.

Russian and Chinese themes dominated the statements of D. Trump and J. Biden on international issues during the election campaign. Though the Democratic candidate often preferred to use relatively more diplomatic language in his assessment of the Russian politics than the one used by many American legislators and liberal media, his sharply negative attitude towards Russia as the main geopolitical adversary of the United States is beyond doubt. He characterized China as the strongest competitor, without calling it an enemy. Democrats accused D. Trump of indulgence towards Moscow's ambitions and "pliability" towards the leaders of authoritarian and dictatorial regimes.

The revival of American leadership was a recurrent theme in J. Biden's campaign statements. The Democratic leader promised to eradicate the isolationist tendencies in foreign policy, which, in his opinion, had been cultivated by the Trump administration, causing discord with the allies and undermining the U.S. influence in international institutions. However, the election platform adopted at the Democratic Convention gives only a most general idea of the agenda that they offer to the country: overcoming the coronavirus pandemic as early as possible, implementing a wide range of economic and social security measures, transition to "clean energy" and creation of a climate-friendly infrastructure. Speaking online to the Convention, J. Biden promised to unify the nation and "put an end to the dark period in the U.S. history."

During the election campaign, J. Biden emphasized that D. Trump had inflicted enormous damage to the international image of the United States. $\mathrm{He}$ stated that in the recent years, the influence and trust in the United States in the world had decreased, that «President Donald Trump has belittled, undermined, and in some cases abandoned U.S. allies and partners» and by his policy had caused their alienation; «has launched ill-advised trade wars, against the United States' friends and foes alike, that are hurting the American middle class»; " has abdicated 
American leadership in mobilizing collective action to meet new threats" and "turned away from the democratic values that give strength to our nation"; cut funding and downplayed the significant role of the U.S. diplomacy [Biden J. 2020: 64, 71, 73]. The Democratic candidate promised to raise the status of American diplomacy to the level of Washington's main foreign policy instrument. The primary goal, he said, is to restore trust in the United States and American politics, which "Trump had undermined".

D. Trump in his election battle with J. Biden widely exploited the issue of the "Chinese challenge", believing that his opponent had weak positions in this area, despite the fact that Democrats also support tough policy towards China and, in fact, are not much different from Republicans, offering a less aggressive modus operandi to achieve the same goals. However, D. Trump actively played up his rival's "Chinese blunders", accusing him of having taken part in the adoption of laws and decisions that could strengthen China and turn it into a dangerous competitor of the United States. According to Trump, Biden had voted for "voted to ship our jobs to China".

D. Trump also reminded that the Democratic candidate had once supported the NAFTA trade agreement, which created unequal conditions for many American manufacturers in comparison with their competitors, especially in the automobile industry [2]. Trump's campaign headquarters, in its statement of August 26, 2020, accused Democrats of completely ignoring the threats that China poses to the U.S. economy and national security and avoiding a discussion of this issue at the Democratic Convention that had ended the day before. And when Director of the U.S. National Counterintelligence and Security Center W. Evanina announced on August 7 that, according to his department's estimates, the Chinese authorities would prefer that D. Trump, whom they regard as an unpredictable politician, not be re-elected for a new term, Republicans, with renewed energy, launched the idea that China counts on J. Biden's victory. They tried to play on the mood of the American society, which, in the poll conducted in July by the Pew Center, showed the lowest level of positive perception of China in the entire history of these surveys. In the keynote speech, delivered immediately after his nomination as the official presidential candidate by the Republican Party, D. Trump mentioned China 15 times in a negative way, including 7 times in direct connection with J. Biden [3]. People from D. Trump's inner circle, including his personal lawyer R. Giuliani, accused Hunter Biden of receiving a substantial amount funds from Chinese investors in exchange for the political influence of his father when he was Vice President. J. Biden was also accused of neglecting the problem of human rights violations in China. The "China card" was also played by the Republicans in the context of the situation with the coronavirus pandemic. The Trump administration tried to switch the attention of the American society from its blunders in responding to this threat, which it had initially underestimated, to China as the source of its emergence.

Despite differences in opinion on many issues of international politics and world economy, J. Biden and D. Trump agreed that the strengthening of China should be the primary focus of the United States' attention in the foreign policy affairs. At the same time, each of them put his own emphasis in the "Chinese issue". D. Trump called China a systemic threat to the United States, given China's ability to influence the world order, which no other American rival has. J. Biden defined China as the main economic competitor, and Russia as the main threat to the national security of the United States and American alliances. Such differentiation reflects J. Biden's desire to avoid the simultaneous involvement of the United States in total confrontation with both the Russian Federation and China.

Both presidential candidates in their interviews and public speeches before the November 3, 2020 elections several times touched upon the Middle East issue. D. Trump confirmed his promise given previously during the election campaign to stop "endless wars" and curtail the large-scale U.S. military presence in the region. In September, the United States Central Command announced the forthcoming reduction of forces in Afghanistan from 8.6 thousand to 4.5 thousand people and the decrease in the number of the American troops in Iraq from 5.2 thousand to 3 thousand people. J. Biden, for his part, also stated that he supports the reduction of American troops in the Middle East.

\section{AN ADJUSTMENT OR A COMPLETE REVISION OF THE U.S. FOREIGN POLICY?}

The 2020 presidential election became a watershed between Trump's "America First" policy and the liberal revenge that J. Biden's team is preparing in domestic and foreign policy. The new President has made it clear that he intends to return the U.S. foreign policy to the pre-Trump path: to revive friendly relations with allies in Europe and Asia, to reaffirm American commitments to security and to the climate change problem by restoring the country's participation in the Paris Agreement and to encourage other countries to reduce carbon emissions on an even greater scale. According to Biden's own admission which he made in the middle of the presidential race, he does not have a foreign policy concept 
ready, but he has a plan for the restoration of American leadership, based on the assumption that if the policy pursued by D. Trump is not changed, then either some other country will take the place of the world leader instead of the United States, or it will remain vacant, which will lead to chaos.

In his article in Foreign Affairs magazine published in spring 2020, J. Biden stated that there is a decline in the trust in democratic institutions all over the world. Democracy is under the greatest pressure since the 1930s, he said, "the international system that the United States so carefully constructed is coming apart at the seams".

A big problem is tension in the U.S. relationship with NATO, whose members are concerned that "America First" means "America acting alone." J. Biden promised, if elected, «to take immediate steps to renew U.S. democracy and alliances, protect the United States' economic future, and once more have America lead the world». He identified the organization of a "summit for democracy" in the first year of his presidency as one of the priority goals so that the leaders of democratic countries could agree on a common agenda for joint action in three main areas "fighting corruption, defending against authoritarianism, and advancing human rights" [Biden J. 2020: 65, 67]

J. Biden promised to stick to a multilateral approach in international relations, to restore the trust of the allies to American obligations, their confidence in that they can count on the protection of the United States. Unlike D. Trump, as Biden emphasized in his article, he believes that international institutions and cooperation with foreign partners are necessary for the implementation of the U.S. foreign policy goals, and he is convinced that alliances and coalitions expand American opportunities in international affairs and strengthen the country's influence in the world. Biden promised to try to secure the support of the allies in specific situations when American interests demand it, and not because of abstract considerations about the value of allied solidarity and the important role of multilateral diplomacy.

J. Biden called the course he proposed as "foreign policy for the middle class", defining its goals in the following way: ensuring the U.S. leadership in the global economy, "win in the competition for the future against China or anyone else";=working "to make sure the rules of the international economy are not rigged against the United States"; "taking down trade barriers" resisting a dangerous global slide toward protectionism". He proposed to unite the might of democracies around the world "to counter abusive economic practices and reduce inequality" [Biden J., 2020: $68,69]$. The answer to the main question - who will determine the rules of world trade? - is quite obvious, in his opinion: the U.S., of course, not China.

The Biden administration, which began service on January 20, will continue the strategy of containing Russia, most likely in a new version, which envisages the creation of a wider international front of sanctions and geopolitical pressure on Moscow. In its policy of countering the Russian Federation on the post-Soviet space one can expect harsher actions, not just harsh rhetoric. Back when J. Biden was Vice-President in the administration of B. Obama, he tried to convince him to punish the Russian Federation more decisively after the events in Ukraine in 2014. The nomination of the "centrist hawk" A. Blinken, who has repeatedly made harsh attacks on Russia's policy, to the post of U.S. Secretary of State fits into the logic of the "extended containment" strategy, which the new administration intends to build against the Russian Federation in coordination with its allies and satellites.

One of the few areas where J. Biden expressed his readiness to seek an agreement with Moscow is the limitation of nuclear weapons, primarily the extension of the START-3 Treaty, which, as he put it, is an anchor of "strategic stability between the United States and Russia" [Biden J., 2020: 75]. In his article J. Biden promised to return the United States to the path of arms control obligations and to prolong the abovementioned treaty.

The new U.S. President is known for his support for the idea of Ukraine, Georgia and the Balkan countries joining NATO. It is quite obvious that the Biden administration will act energetically in favor of accelerating the integration of these countries into the North Atlantic Alliance, despite the objections of the continental European powerswhich are afraid of sliding into a military confrontation with Russia. From Washington we can expect activity aimed at feeding instability and tension along the perimeter of the Russian border as well as attempts to manage conflicts in neighboring countries, including Ukraine, Belarus and the countries of theTranscaucasia regionin order to weaken and drain the resources of the Russian Federation.

J. Biden will continue D. Trump's policy of squeezing Russia out of the European energy market, supporting the U.S. Congress in initiating sanctions aimed at blocking the completion of the Nord Stream-2 gas pipeline and hindering other similar projects.

For many reasons, relations with China will be the main foreign policy priority of the new administration. Taking into account the stable bipartisan consensus on the "China issue", J. Biden will continue to implement the strategy of active counteraction 
against the strengthening of China. Washington will try to influence Beijing's behavior in APAC and restrain its actions in the region by various means, avoiding, if possible, increasing the level of the U.S.Chinese military confrontation. J. Biden's approach is characterised by the desire to take action on a $\mathrm{mul}$ tilateral basis, coordinatingmeasures on curbing activity and limiting the influence of China with allies and partners. At the same time, he expressed his readiness to cooperate with Beijing on those issues where the interests of the two countries coincide climate change, non-proliferation of nuclear weapons, security in the field of international health.

With the goal of building a broad geopolitical coalition against China, the new administration will try to draw as many countries as possible into it, and not only regional allies. European countries are concerned about the confrontation between the United States and China and do not want to be drawn into rivalry between them. They prefer to talk about the rise of China only as an economic challenge from a competitor with a huge growth potential, and in $p u b$ lic policy they do not assess it as a threat to national security, trying to avoid confrontation with it in all ways, given the great importance of bilateral trade and economic ties for their own economies.

The new U.S. administration will have to negotiate atrade agreement withChina in order to prevent the escalation of the "tariff war" between the two largest economies in the world. The new administration is limited in its ability to make serious concessions here, given China's huge surplus in bilateral trade, and being potentially vulnerable to accusations of unjustified softness of its position, which, when discussed in the U.S. Congress, will inevitably be compared to that of D. Trump, who pursued a tough course and enjoyed bipartisan support in this issue.

In stark contrast to the "Trump era" policyJ. Biden promised to restore friendly relations of the United States with its European allies and to de-escalate the transatlantic trade conflict. Democrats believe in the value of U.S.-centered alliances and see them as important structural elements of the liberal world order. J. Biden, as opposed to D. Trump, will not use the issue of the American military presence in Europe to force concessions from the allies in trade and economic disputes. He will try to restore the Europeans' confidence in America's defense commitments and restore the role of the North Atlantic Alliance as a mechanism for coordinating the strategy of the United States and Europe. J. Biden considers NATO to be the most important alliance in history, the basis of American power in Europe and the foundation of the collective security of the West. He will most probably suspend or even completely cancel his predecessor'splans to reduce American troops in Europe (in Germany, in particular), in Japan and in South Korea, and he will continue to build up the U.S. military force in Poland.

The new administration will have to take a more flexible position on the distribution of the burden of defense spending between the U.S.and its allies, rejecting the tough pressure exerted on them by D. Trump, since this issue has become especially sensitive for Europeans due to the "suffocating" approach of the previous administration and the dire economic consequences caused by the COVID-19 pandemic. However, the new president is unlikely to lift the requirement that the allies allocate at least $2 \%$ of GDP for defense (in 2020, only 10 out of 30 NATO countries met this criterion). J. Biden will continue D. Trump's line of lobbying the interests of American military-industrial corporations in Europe, demanding that EU regulation, especially the one on the European Defence Fund, not hinder their activities in the European arms market.

As for the Middle East, J. Biden promised to rearrange American policy in the region. He admits the possibility of negotiations with Iran on a nuclear deal, but only under certain conditions. For example, he is ready to restore theparticipation ofthe U.S.in the agreement on the limitation on Iran's nuclear program, to gradually remove the economic sanctions imposed by $\mathrm{D}$. Trump and, after he is convinced that Teheran strictly complies with all the terms of the 2015 deal andagrees to limit the development of ballistic missiles, to curtail the "destabilizing" U.S. activity in the region. Within the framework of the package agreement, the new administration may include Iran's compliance with the international arms embargo regime into the list of its requirements, despite the fact that since October 18 , 2020 this regime has lost its legal force.

Back when he was still a contender to the U.S. presidential nomination, J. Biden promised to return home most of the American troops from Afghanistan and reduce American military presence in other countries of the region, believing it necessary to maintain a small number of troops there - a contingent of special operations forces of 1,5-2 thousand people to fight the terrorist groups that pose a threat to the United States and its allies. In his opinion, the administration should strictly define the objectives of the American military presence- to conduct operations together with allies and partners against al-Qaeda, ISIS and other terrorist organizations, as well as to assist the countries of the region in training special forces, without interfering with their internal political affairs. J. Biden admitted that he is not prepared to promise a complete withdrawal of troops 
from Syria, Afghanistan and Iraq in the near future [4]. From his administration, one can expect increased support to the forces of the Syrian opposition, including the Kurdish formations, as well as the strengthening of the American military presence in north-eastern Syria, which allows to maintain control over the local oil production. J. Biden is in favor of ending American assistance to Saudi Arabia in the war that it is conducting in Yemen, and his administration, apparently, will decide to curtail the assistance that Saudi Arabia and the UAE received from the United States while conducting military operations in Yemen and Libya. Obviously, it was easier for the monarchies of the Persian Gulf and for Egypt to work with the Republican administration, which was guided by pragmatic considerations and did not promote the human rights issues in bilateral relations and regional politics.

While the approaches of the new President towards relations with China and the U.S. military participation in the affairs of the Middle Eastlargely coincide with the views of his predecessor, they differ fundamentally on the issue of the foreign trade strategy. The Democratic President positions himself as a zealous champion of free trade, but he also tried to intercept some of his rival's slogans by proposing the "proAmerican worker trade strategy." J. Biden condemned D. Trump's decision to qualify the import of certain categories of goods from politically close countries from Canada to the EU - as a threat to national security, which had served as a reason for introducing trade duties against allies [Biden J., 2020: 70]. There are obvious contradictions in his views. On the one hand, he criticized D. Trump for unleashing a trade war against China, which, according to him, had protected the interests of big business but negatively affected ordinary Americans; on the other hand, he stated that his policy towards China would be just as tough.

J. Biden stated that as President, he intends, like his predecessor, to carry out "aggressive coercive measures" in trade against those countries which, in his opinion, manipulate exchange rates or use other off-market trading practices. However, unlike D. Trump, he intends to make sure he has the support of American allies in this matter and take such actions on a multilateral basis, building with them a united front against China's abuse of trade and violations of human rights. Another difference is the plan announced by $\mathbf{J}$. Biden to introduce an additional "carbon tax" on goods entering the United States from foreign countries that do not fulfil their obligations under international agreements on climate and environmental protection. In his opinion, this measure will not allow countries with a high level of environmental pollution to undermine American industries. However, during his tenure as Vice-President in the Obama administration, he ignored the negative environmental consequences that accompanied the rapid growth of shale oil and gas production in the United States. Now he is ready to launch another energy strategy, the goal of which is to remove hydrocarbons from the U.S. power generation system within 15 years' time and to stop all green house gas emissions in the economy by 2050 . J. Biden believes that restructuring the energy sector in the new direction will allow American economy to faster overcome the recession caused by the coronavirus pandemic.

\section{DEBATES ON THE U.S. FOREIGN POLICY AT THE NEW STAGE}

The 2020 election campaign, in the course of which two fundamentally different concepts of America's positioning in the world clashed, gave new impetus to the debate on foreign policy the U.S. Many politicians and experts of liberal views admit that the Post-Cold War world order has entered its period of disintegration. However, while some of them tend to think that the main reason for this is that the U.S., under D. Trump, willingly refused to support the liberal world order and even took part in its destruction, others find deeper reasons behind this process, citing, primarily, the process of political deformation of the United States itself and global shifts in the world balance of power, which undermine the foundations of American hegemony.

J. Biden promised that if he wins the elections, his administration will try to revive the liberal world order. The idea of a liberal revenge is being nurtured in the political and expert circles of the influential part of the ruling elite. As the American political scientist J. Aikenbury notes, «it would be a grave mistake for the United States to give up any attempt to rescue the liberal order and instead reorient its grand strategy entirely toward great-power competition» [Ikenberry J., 2020: 142].

The balance of power in the Biden administration between the "crusaders" of liberal ideas and the moderate wing of pragmatists can largely determine specific steps to implement a new foreign policy course. If supporters of interventionist policy get greater influence, this will be an indicator of Washington's inclination to use military force to promote and protect "democracy and liberal values" in the world. A. Blinken, proposed by J. Biden for the post of U.S. Secretary of State, showed himself as a champion of "liberal interventionism" - he advocated U.S. military intervention in Bosnia, Kosovo, Iraq and Libya when he worked in the administrations of B. Clinton and B. Obama. 
Former employee of the National Security Council B. Rhodes suggested that many representatives of the foreign policy establishment will, out of old habit, try to convince the new administration to restore the role of the world hegemon to the United States, but restoring this status is, in his opinion, an unrealistic task. He admits that "American democracy itself $<\ldots$ $>$ is no longer the exemplar it once was". The U.S. claims to world leadership to a large extent stemmed from the perception of American democracy as an example for other nations, and now the world has lost confidence in it [Rhodes B., 2020: 48]. American political scientists J. Lind and D. Press agree with B. Rhodes saying that "in the United States and among several of its core allies, large parts of the public have lost confidence in the liberal project that long animated Western foreign policy". In the United States a debate continues on the fruits of the liberal hegemony that the United States has held since the end of the Cold War: whether it produced the desired results "the country squandered its power and expedited a return to multipolarity. Yet whatever the verdict, it is clear today that the United States' geopolitical vacation is over and that a major course correction is due" [Lind J., Press D., 2020: 48].

The left liberal wing of the expert community offers an alternative concept of foreign policy o the new administration, which envisages the adaptation of the United States to a world where there will be no American hegemony. As the political scientist R. Lebow admitted, this concept contradicts many accepted postulates of the military-political establishment. Its initial premise is that the United States has no opportunity to restore the "hegemonic model" of the world order, since this model is viable only when other countries accept the set of rules and regulations proposed by the United States. According to $\mathrm{R}$. Lebow, the hegemonic foreign policy led to huge expenses and costly military intervention in Afghanistan and Iraq and, as a result, many elements of infrastructure, social programs and investments in the economy suffered in the U.S. itself. Besides, the unjustified use of force abroad undermined the American influence and legitimacy of Washington's claims to world leadership [Lebow R., 2020: 197, 198]. He suggests that in international policy the Democratic President act by persuasion and by formulating an international agenda rather than by force and coercion, thus returning the policy to American values. However, R. Lebow seems to forget that these values themselves have become the subject of fierce disputes and are already being interpreted in two different ways by the opposing political forces in the country.
When the patriarch of American diplomacy $\mathrm{H}$. Kissinger wrote seven years ago that different political and civilizational centers of the world have largely incompatible concepts and ideas about the world order, he could hardly foresee that there would soon be a split among the U.S. ruling elite on this issue. However, he clearly understood "world order cannot be achieved by any one country acting alone", even if, according to objective criteria, it is the most powerful country in the world [Kissinger H., 2014: 373].

\section{CONSEQUENCES FOR TRANSATLANTIC RELATIONS}

The relationship between the United States and Europe (EU) in recent years has suffered unprecedented tension and mutual distrust. The Trump administration did not accept the EU's proposal to coordinate measures to combat the COVID-19 pandemic, which would include the creation of joint stocks of medical supplies, intensification of work on unifying the rules and regulations for medical devices, medications and vaccines. It also refused to support the EU's initiative to form an international fund to finance the development of a vaccine against coronavirus, hoping that the U.S. would win in the "vaccine race" that started among the world's leading powers. D. Trump accused the World Health Organization of the acceptance the errors made by the Chinese authorities, who had "missed" the outbreak of the coronavirus epidemic. He called the WHO a "puppet of China", announced the termination of the payment of membership fees and the withdrawal of the U.S. from this organization [5]. D. Trump's destructive position further undermined Europe's confidence in his policy which rejected multilateralism even in those cases when international cooperation is needed cope with the epidemiological crisis and mitigate its economic consequences [Welfens P., 2020: 301, 303].

Against this background, the statements of J. Biden in favor of the revival of true allied relations with $\mathrm{Eu}-$ rope sounded as striking contrast. The 46th President of the United States sees the EU as a partner in rebuilding the crumbling structures of the liberal world order, countering Chinese influence in international organizations (IMF, WTO, etc.), establishing close cooperation in combating terrorism and in climate protection. From the J. Biden's statements we can assume that he will try to quickly overcome the consequences of Trump's policy in the transatlantic relations, which suffered from it. The 46th President of the United States sees the European Union, which unites 27 European countries, as an antidote to the revival of nationalism in Europe. In his opinion, the EU plays an important role in ensuring regional security and stability. J. Biden is supported 
by those leaders who rely on the parties of the establishment and reflect the views of the political mainstream, while Washington, for its part, intends to pursue a policy aimed at limiting the influence of populist and nationalistic parties and movements in Europe.

The promotion of A. Blinken who has been working in the international politics for over thirty years (of these about twenty years- side by side with J. Biden) and is well versed in European affairs, to the post of U.S. Secretary of State suggests that cooperation with Europe will be one of the priority areas of the new administration's international activity. As some Western observers noted, A. Blinken, who spent his childhood in France, takes to heart the fear that the French feel about the possible collapse of the European integration project, and, naturally, he will do everything possible so that the EU does not collapse. The choice of this candidate by J. Biden signals the return of the United States to multilateral cooperation and the rehabilitation of transatlantic relations. This decision was generally well- received by the American foreign policy establishment.

In foreign policy, J. Biden, unlike his predecessor, attaches great significance to the issues of the promotion of democracy, supremacy of law, protection of human rights and liberal values. This can add additional irritation to Russian-American relations, as well as cause friction between the United States and some Eastern European countries, mainly Poland and Hungary, which had established mutual understanding with the previous administration.

It seems that no matter how strongly J. Biden's administration tries to distance itself from D. Trump's policy, it, too, will demand from its European partners close coordination on issues related to China's investment and technological expansion in Europe, requiring that they carefully monitor China's penetration into sensitive sectors of the economy, such as high technology, telecommunications, transport infrastructure and energy. However, contradictions will remain between Washington and its European allies on what would be the best way to respond to China's economic challenge. The new administration will undoubtedly try to reach agreement with the EU on this issue, but it will hardly follow the tactics of D. Trump, who used various threats to force European partners to reject cooperation with China, in particular of the supplies of the equipment for mobile networks of the fifth generation (5G) to Europe. Rather, it will try to persuade the allies not to use it due to security concerns. We can be reasonably sure that the U. $\mathrm{S}$. is not eager to help the EU countries in every issue where they have problems with China and where Chinese actions threaten European interests. Europe's interest in cooperation with China may hinder the plans of the Biden administration to involve the EU in putting pressure on Beijing over the political situation in Hong Kong and human rights issues concerning, in particular, the situation of the Uighurs in Xinjiang. In any case, the European allies will resist attempts to drag them into the U.S.-China confrontation.

J. Biden's presidency is likely to ease the tension in transatlantic trade relations and the ending of the escalation in tariff disputes between the U.S. and the EU. The new president will not threaten Brussels with an increase in duties on European cars (D. Trump planned to apply this measure if trade negotiations fail). The new administration will probably cancel the increased tariffs on European steel and aluminium set by the U.S. government in June 2018. At the same time, Western experts do not expect the resolution of the problems that hinder the conclusion of a full-scale trade agreement between the United States and EU in the near future. The arrival of J. Biden to the White House does not eliminate the fundamental disagreements between the parties on some issues, for example, on standards for food products and conditions for the access to the agricultural market. The new U.S. administration is unlikely to accept the EU's proposal to sign a treaty on those issues on which agreement has been reached (industrial goods, mutual recognition of procedures for verifying the conformity of goods with the respective requirements, etc.), since the U.S. Congress will not ratify an agreement that will not open the European market to American farmers' products.

J. Biden also inherited the disagreements between the U.S. and the EU on the taxation of big players in the digital services market, which are primarily American companies Facebook, Amazon, Apple and Google. Washington may return to the multilateral negotiations held in spring 2020 under the auspices of the OECD if European countries abandon their plans of introducing a "digital" tax unilaterally. The intention of the European Commission to fine American Internet companies for violating the rules of competition in the European market or to impose a special tax on the activities of big players in the digital services field will most certainly cause friction with Washington.

The arrival of J. Biden at the White House does not necessarily mean the resolution of disagreements between the U.S. and the EU on the issue of personal data protection either, given the July 2020 ruling of the EU Court of Justice, which invalidated transatlantic "Privacy Shield" agreement as inconsistent with the legislation of the European Union, due to the lower security standards adopted in the United States. The American side is unlikely to change its federal and local rules for the sake of an agreement with the EU. The change of administration in Washington will not automatically end the dispute between the U.S. and the EU over government 
subsidies to Boeing and Airbus. On November 10, i.e. when it was already known about the victory of the Democratic candidate, the EU imposed duties on American goods worth about $\$ 4$ billion following the WTO decision on government subsidies to Boeing [6]. Nevertheless, this will hardly become an obstacle to cooperation between the U.S. and the EU on the issue of updating the WTO rules. J. Biden intends to distance himself from the policy of his predecessor who was in opposition to this organization. Washington will almost certainly agree to the appointment of new members to the WTO Appellate Body in order to bring it back to full functioning. The possibility of such a change in the American position was noted by some people from J. Biden's entourage, but this does not guarantee the unity of the views of the United States and the EU on all aspects of the WTO, since Washington's friction with this organization began long before Trump's time, and it will not disappear with his departure from the White House.

\section{CONCLUSION}

The results of the U.S. presidential election were the milestone that ended the "Trump era" in American politics. J. Biden's victory means not only a change of administrations representing the main competing forces in the country, but a political revenge of the liberal part of the American ruling elite. However, despite the euphoria of victory, the Democrats will hardly be able to completely eradicate the consequences of Trump's policy, given the scale of its electoral support.

It would be a simplification to assert that disagreements between Republican D. Trump and Democrat J. Biden followed solely the disagreements between the parties. In them two thoroughly different visions of the future of the United States and their role in international relations clashed. Many Western political scientists predicted that the 2020 U.S. presidential election, whatever its outcome is, would not lead to the disappearance of political polarization in the American society. They also agreed that D. Trump's re-election would significantly reduce the chances for the revival of the liberal world order [Fukuyama F., 2020: 32]. However, the defeat of the 45th president does notmean that" Trumpism" can be regarded as an accidental deviation in the political history of the United States and irrevocably written off as an archive: in 2020, the Republican candidate received the support of more than 74 million Americans, which is 10.7 million votes more than four years before.

One of the factors that influenced the election results was D. Trump's inability to fully consolidate the ranks of Republicans and expand the base of his electorate. His policy was unacceptable to the "old republican guard", which is part of the establishment: Bush Sr., Bush Jr., J. Baker, D. Cheney, R. Dole. A number of prominent politicians, including former Secretary of State C. Powell and Senator M. Romney expressed disagreement with President's policy and spoke out against his re-election. D. Trump was also criticized by several Republican senators, among them B. Sasse and T. Cruz. There were some Republicans who even changed their party preferences and went over to the Democrats. J. Gaylord, who served as a senior adviser to N. Gingrich, former Speaker of the House of Representatives, speaking to the Republican Convention at the end of August said that D. Trump had actually done a revolution in the party, having returned it to its historical roots - protectionism and isolationism which date back to the pre-war era, and in this he challenged the establishment that had run the party from 1980 to 2016. According to J. Gaylord, this alienated from D. Trump those Republicans who were closely associated with the political mainstream. The support of D. Trump by the Republican party elite diminished even further after the storming of the Capitol on January 6 by a crowd of supporters of the 45th president who did not agree with how the election results were finalized. The then head of the White House was charged with inciting violence that resulted in several deaths.

D. Trump's policy was also rejected by some political and expert circles close to the Republican Party. Since the end of 2019 there appeared several antiTrump groups with ideological ties to Republicans the Lincoln Project, the Bravery Project and others who stood in opposition to the White House, stating that "Trumpism destroys the country." A significant group of former high-ranking State Department and NSC officials (more than 70 people) who at various times had worked for the Republican administrations, including former Deputy Secretary of State R. Armitage and former Assistant Secretary of State J. Kelly, united in support of J. Biden and published a statement claiming that President had "endangered American security." In it they formulated ten theses that explain the essence of their claims against D. Trump which practically coincide with the opinion of the Democrats. [7].

Politicians and experts on both sides of the Atlantic attached extreme importance to the results of the 2020 presidential elections. In the liberals' forecasts there were apocalyptic warnings that the Atlantic community in the shape it acquired after World War II may not survive another four-year term of Trump's presidency. The election of J. Biden was perceived by liberal circles as a chance to reset transatlantic relations. However, the new administration will hardly be able to fully eliminate the consequences of Trump's policies, including the one in the 
European area. The allies cannot be fully sure that the United States is immune to the political revenge of "Trumpism", perhaps in its new version, especially if the Democratic administration will not be able to avoid liberal excesses in its policy. J. Biden is the President of one term, and it is unclear what the situation in the United States will be like by 2024. The results of the 2020 vote show that D. Trump's ideas have quite a wide support in the American society, and Europe will have to take this into account. There are no guarantees that a politician whose views are close to those of D. Trump will not win in the next presidential elections in the United States.

Political and ideological biases do not allow the opponents of the 45th president to objectively look at the results of his activities "Trump's critics rounded on him for rejecting the Paris agreement on climate change. But during his presidency, the US has made more progress cutting greenhouse gas emissions than most industrial competitors. $<\ldots>$ Moreover, the US now enjoys energy self-sufficiency, enabling the country to reduce its dependence on fossil fuels from the Middle East - a huge geopolitical boost. Trump has achieved what Obama never quite could and scaled back America's interventionist foreign policy" [8].

According to American liberal political scientists, the crisis caused by the coronavirus epidemic meant the "collapse of the American superpower" [Rhodes B., 2020: 52]. A. Cooley and D. Nexon believe "in many respects, the covid-19 pandemic seems to be further accelerating the erosion of U.S. hegemony" [Cooley A., Nexon D., 2020: 154]. Failures in transatlantic cooperation were especially visible against the background of the active "mask diplomacy" of China, that sends medical supplies to various regions of the world and which is much more effective in overcoming medical and economic consequences of the crisis. According to F. Fukuyama, as a result of the "the global distribution of power will continue to shift eastward, since East Asia has done better at managing the situation than Europe or the United States" [Fukuyama F., 2020: 28].

The 2020 elections were marked by an extremely antagonistic rivalry between the two main presidential candidates which reflected a deep division within the society. The voting results are the starting point for a new stage in American foreign policy. The new President intends to annul some of his predecessor's landmark decisions, which may help ease tensions between Washington and Beijing, at least on some of the issues of bilateral and international relations. Overall, however, the intensity of the U.S.-China confrontation will hardly subside. J. Biden's plans to revise the previous administration's policy towards Europe find support in the allies, which promises a warming in transatlantic relations; the remaining contradictions will not acquire such harsh forms as during D. Trump's presidency. The prospect of geopolitical distancing and Transatlantic trade war no longer looks realistic: Washington and Brussels are interested in reducing the intensity of rivalry on controversial issues and in demonstrating loyalty to Atlantic solidarity. However, disagreements remain between them in the assessment of China's policy and events in the Middle East, while the accumulated amount of unresolved problems in trade and economy is so significant that it requires considerable concessions from them, which they failed to make even in the "blessed time "of B. Obama's presidency.

\section{REFERENCES}

1. Biden Joseph R. 2020. Why America Must Lead Again: Rescuing U.S. Foreign Policy After Trump // Foreign Affairs. March-April. Vol. 99. No. 2. P. 64-76.

2. Cooley A., Nexon D. 2020. How Hegemony Ends // Foreign Affairs. July-August Vol. 99. No.4. P. 143-156.

3. Fukuyama Francis. 2020. The Pandemic and Political Order // Foreign Affairs. July-AugU.S.t. Vol. 9. No.4. P. 28-32.

4. Heisbourg François. 2020. From Wuhan to the World: How the Pandemic Will Reshape Geopolitics // Survival. June-July. Vol. 62. No. P. 7-24.

5. Ikenberry John. 2020. The Next Liberal Order // Foreign Affairs. July-AugU.S.t. Vol 99. No.4. P. 133-142.

6. Kissinger Henry. 2014. World Order. New York: Penguin Press, 2014. 420 p.

7. Lebow Richard N. 2020. A Democratic Foreign Policy: Regaining American Influence Abroad. London: Palgrave Macmillan, $220 \mathrm{p}$.

8. Lind J., Press D. 2020. Reality Check: American Power in an Age of Constraints // Foreign Affairs. MarchApril. Vol. 99. No.2. P. 41-48.

9. Rhodes Ben. 2020. The Democratic Renewal // Foreign Affairs. September-October Vol. 99. No.5. P. 46-52.

10. Sperling James. 2019. American Leadership of the Atlantic Alliance post-Kosovo. Comparative Strategy. Vol.38. No.5. P. 409-425.

11. Welfens Paul J. 2020. Macroeconomic and Health Care Aspects of the Coronavirus Epidemic: EU, U.S. and Global Perspectives // International Economics and Economic Policy. May. Vol. 17. No. 2. P. 295-362. 